\title{
Informal Economy of Dhaka City (South): Situation and Facts
}

\author{
A H M Shahidul Islam \\ National Consultant, Strengthening Public Investment Management System Project \\ Programming Division, Planning Commission, People's Republic of Bangladesh \\ ahmshahidul@hotmail.com
}

\begin{abstract}
The informal sector or informal economy is the part of an economy that are not taxed, regulated, monitored or included in the gross national product (GNP) by any form of government. This paper attempts to expresses the current situation of the informal economy of Dhaka City (South) as well as marginal propensity to consume (MPC) and marginal propensity to save (MPS) of the vendors by using Keynes consumption function. In addition, this paper also tries to illustrate the overall scenario of these vendors. To exemplify the result this study used primary data of 50 vendors of the areas of five different locations of Dhaka City (South) in the month of April, 2016. Moreover, this study finds that MPS of most of the vendors of the informal sector of Dhaka city (South) is small due to their higher MPC. As a result, it leads to low investment, which might have a significant impact in the economy. In light of the general poverty, low technology and development, informal activities are often considered as an economic, political and social value for public discontent. Nevertheless, transformation in the long run is a necessity for these countries as well.
\end{abstract}

\section{INTRODUCTION}

The Informal Sector or Informal Economy as defined by governments, scholars, banks etc. is the part of an economy that are not taxed, regulated, monitored or included in the gross national product (GNP) by any form of government. Sometimes it called "under the table, unlike the formal economy. It is often associated with developing countries, where up to $60 \%$ of the labor force (with as much $40 \%$ of GDP) works; all economic systems contain an informal economy in some proportion. Similarly, the sector is also very important area of the economy for Bangladesh; it is a growing occupational sector for the less skilled people, living both in urban and rural areas. Considerable amount of employment are ensured by this sector. What is specific to the informal economy is the absence of rights and social protection of the workers involved in it. Living in extensive poverty; exploited, with no place to go for protection; lacking access to basic social services; no basic safety conditions at work; holding little or no hope that life can be better; struggling on a daily basis just to survive, they are street vendors, wage laborers working in small enterprises on a regular, casual or contract basis; unpaid workers including family workers and apprentices, home-workers, paid domestic workers and more; and a smaller number are the owners of tiny enterprises.

In Bangladesh, 87 per cent of the labor force is employed in the informal economy according to the Labor Force Survey 2010. Those working in the informal economy include wage laborers, self-employed persons, unpaid family labor, piece-rate workers, and other hired labor. The only way to earn a living for people who are selfemployed outside the formal economy and not on anyone's payroll. Most of them don't live and work in this sector because it is their wish or choice, but because they have no chance to be hired by an employer from the formal sector except for a few hours or days with no legal right to be hired again. The term informal sector was used in many earlier studies, and has been mostly replaced in more recent studies which use the newer term. 
At one time, no attention was given by economists to economic activities carried out outside the formal framework of the economy. Sociologists and anthropologists were the only ones who even seemed to consider the existences of such activities. In the 1950s and 1960s, however, the informal dimensions of organizational life became increasingly recognized as important and were accepted as a commonplace topic for research (Blau and Scott, 1963; Gouldner, 1954).

However, an accurate academic meaning was not given to this neglected phenomenon until it was analyzed in 1972 by the International Labor Office (ILO), under the name 'informal sector'. As a matter of fact, the 'informal sector' concept originates from a study in a Third World context (Hart, 1971). It was in the Third World countries that the informal sector was initially observed and studied, followed by the increased interest in developed countries. Eventually, significant studies about less developed countries, a few on former socialist countries (mainly about the former Soviet Union), and more recently (in the last ten years) about transition countries started to appear. The academic thinking about the informal sector was really advanced by these studies about less developed and transition countries, where the influence of the 'informal sector' is much more significant than in other countries.

Without street vending in urban areas a large number of urban dwellers fall into a critical situation in their lives. Not only the low-income group but also the middle-income group of urban dweller depends on street vendor for shopping in their life. According to the Dhaka City South Corporation (DSCC) report, about 60\% households are laying on the low-income, 37\% middle income and the rest 3\% constitutes high-income level. According the daily Newspaper, venders operate their businesses in Farmgate, Gulistan, and New Market areas paid by 0.5 million BDT (Bangladeshi Currency, Taka. $1 \$=78.56$ BDT at September 2016) per day as an illegal toll to local political leaders and local authorities for unofficial permission. The authority has indicated that street vendor is an illegal trade in urban area of Dhaka City. However, street vending is an essential factor for a large number of urban dwellers to maintain their livelihood. It would be considered that, by the implementing a public management system, street vendors would become a comfort for urban dwellers of Dhaka City as well as become a model for South Asian developing cities.

\section{BACKGROUND AND Motivation}

As previously mentioned, Keith Hart $(1971,1973)$, a social anthropologist, was the first one to bring the term 'informal sector' (in a Third World context) into the academic literature ${ }^{1}$. He introduced the concept of the 'informal sector' as a part of the urban labor force, which takes place outside of the formal labor market ${ }^{2}$. Hart considered the 'informal sector' as almost synonymous for the categories of small self-employed. This was thereafter typically used to refer to ways of making a living outside the formal wage economy, either as an alternative to it, or as a means of supplementing income earned with it (Bromley and Gerry, 1979). In addition, Hart distinguished formal and informal income opportunities on the basis of whether the activity entailed wage or self-employment, implying that wage-earning employment is a characteristic of the formal sector only. Even though Hart's original notion of the 'informal sector' is limited to the 'self-employed', the introduction of the concept was able to incorporate activities that were previously ignored in theoretical models of development and in national economic accounts (Swaminathan, 1991). This was an important characteristic of the subsequent use of the term.

1. Hart's first publication about it seems to have been in 1973, but apparently he used the term already in 1971. 2. It should be mentioned, however, that a casual labor market of a somewhat similar nature (informal) has also been identified in 18th - and 19th -century London (George, 1966; Stedman Jones, 1984). 
In spite of the early work by Hart, the pioneering research on the informal sector is widely considered to be the report of the International Labor Office on employment in Kenya (ILO, 1972). Informality in this report is mainly characterized by the avoidance of government regulations and taxes. Initially, ILO considered the main aim of the informal sector to be the provision of subsistence to families. It related the growth of the informal sector to its positive effects on the labor market and the distribution of income. As a consequence, it argued that solving the problems of the informal sector is only possible if the problems in these domains are solved ${ }^{3}$. After this initial study, ILO carried out numerous research studies on the informal sector, bringing new developments to the field every time. One of these new developments was the recognition of a new aspect of the informal sector ${ }^{4}$, which is its dynamism and potential for economic growth and employment.

Initiated by the well-known research of H. De Soto (1989) and followed by many others, the conceptualization of the informal sector took yet another meaning. This new course of research studied the informal sector in a regulatory framework. In this approach, the legal status is the main element distinguishing informal from formal activities. It relates the emergence of the informal sector to the policies applied. It suggests, therefore, the deregulation of the market and the almost complete abolition of State intervention. Several theories, methodologies, attitudes and policy implications followed in due course, but these initial approaches are recognized as the basic roots of studies of the informal sector.

\section{OBJECTIVES}

The main objectives of the study are to find out the problems and solutions of the business informal sector of Dhaka City (South). More specifically, the objectives are as follows:

- To identify the current situation of informal economy of Dhaka City (South).

- To identify the problems of informal economy of Dhaka City (South).

- To develop the situation of the informal economy of Dhaka City (South).

The structured of the paper: in the chapter 2 describes the related literature and objectives related issues; in the chapter 3 shows the theoretical background of the study which also includes data and methodology of the study; in the chapter 4 illustrated the analysis and findings of the whole study; the final chapter 5 describes recommendation, conclusion and study limitations.

\section{LITERATURE REVIEW}

Informal economic activity is a dynamic process which includes many aspects of economic and social theory. By its nature, it is necessarily difficult to observe study, define, and measure. No single source readily or authoritatively defines informal economy as a unit of study. Several studies define the 'informal sector' in distinct ways. The main issue discussed in the literature has been the significance of the 'informal sector' and its relation to the formal economy.

Keith Hart $(1971,1973)$, a social anthropologist, was the first one to bring the term 'informal sector' (in a Third World context) into the academic literature. He introduced the concept of the 'informal sector' as a part of the urban labor force, which takes place outside of the formal labor market ${ }^{5}$. Hart considered the 'informal sector' as almost synonymous for the categories of small self-employed. This was thereafter typically used to refer to ways of making a living outside the formal wage economy, either as an alternative to it, or as a means of supplementing income earned with it (Bromley and Gerry, 1979). In addition, Hart distinguished formal and

3. It is argued that this approach conforms with Keynesianism which believes on State intervention.

4. Note that the prior belief was that informal sector was composed only of marginal activities.

5. It should be mentioned, however, that a casual labor market of a somewhat similar nature (informal) has also been identified in 18th - and 19th -century London (George, 1966; Stedman Jones, 1984). 
informal income opportunities on the basis of whether the activity entailed wage or self-employment, implying that wage-earning employment is a characteristic of the formal sector only. Even though Hart's original notion of the 'informal sector' is limited to the 'self-employed', the introduction of the concept was able to incorporate activities that were previously ignored in theoretical models of development and in national economic accounts (Swaminathan, 1991). This was an important characteristic of the subsequent use of the term.

In spite of the early work by Hart, the pioneering research on the informal sector is widely considered to be the report of the International Labor Office on employment in Kenya (ILO, 1972). Informality in this report is mainly characterized by the avoidance of government regulations and taxes. Initially, ILO considered the main aim of the informal sector to be the provision of subsistence to families. It related the growth of the informal sector to its positive effects on the labor market and the distribution of income. As a consequence, it argued that solving the problems of the informal sector is only possible if the problems in these domains are solved ${ }^{6}$. After this initial study, ILO carried out numerous research studies on the informal sector, bringing new developments to the field every time. One of these new developments was the recognition of a new aspect of the informal sector ${ }^{7}$, which is its dynamism and potential for economic growth and employment.

Initiated by the well-known research of H. De Soto (1989) and followed by many others, the conceptualization of the informal sector took yet another meaning. This new course of research studied the informal sector in a regulatory framework. In this approach, the legal status is the main element distinguishing informal from formal activities. It relates the emergence of the informal sector to the policies applied. It suggests, therefore, the deregulation of the market and the almost complete abolition of State intervention.

The literature on the 'informal sector' is fraught with terminological confusion (Harding and Jenkins, 1989). Some of the early phrasings of 'informal sector' are the 'bazaareconomy' and the 'firm-centered economy' (Geertz, 1963); the wartime notion of the 'black market' (Smithies, 1984); popular conceptions about the criminal 'underworld', or images of 'the world turned upside down'. Feige (1989) introduces the term 'underground economy', whereas many others have labeled it subterranean, shadow, informal, hidden, parallel, black, clandestine, second, household, etc.

The selection of researchers - listed in the table - who have studied the informal sector is based on several elements; the distinct criteria used to define the informal sector; the work referred to in tables 1 and 2 is generally considered to cover some of the main studies on this topic. In both tables distinguish various definitions by using three main criteria and various sub-criteria. They adopted the main criteria from Harding and Jenkins (1989). These describe 'the institutional patterns with which the society shapes the informal sector'. They are:

- Political

- Economic and

- Social

The more specified sub-criteria, which are used to define the amalgam of the informal sector activities, vary across the main criteria. The main sub-criteria used regarding the political aspect of the informal sector are:

- Government Regulations

- Illegal Activities and

- National Statistics (GNP)

6. It is argued that this approach conforms to Keynesianism which believes on State intervention. 7. Note that the prior belief was that informal sector was composed only of marginal activities. 
Informal Economy of Dhaka City (South): Situation and Facts

The main idea behind this classification is that it captures the influence of the informal sector [involving lack of government regulation, illegal activities and as a consequence substantial errors in measuring the national product (GNP)] in politics and vice-versa. The majority of researchers selected have used the first criteria to define the informal sector (cf. tables 1 \& 2). Feige (1981), as we will see again later, in spite of using several other criteria, emphasizes the 'national statistics' aspect.

\section{TheORETICAL STUDY}

\section{Data and Methodology}

This study is based on the primary data for 50 vendors of the informal sector of Dhaka City (South), including the areas Dhanmondi, Kalabagan, Malibag, Mogbazar and Shantinagar. The authors have selected the respondents randomly and interviewed them. The respondents answered the questions to the best of their knowledge. So the data collection method is interview method. This study uses the data in the month of April, 2016 for 50 business persons of the informal sector of the selected areas of Dhaka City (South).

In the study authors has used the linear regression model using Keynesian theory of consumption ${ }^{8}$ to find out the relationship between consumption and income of the informal sector of Dhaka City.

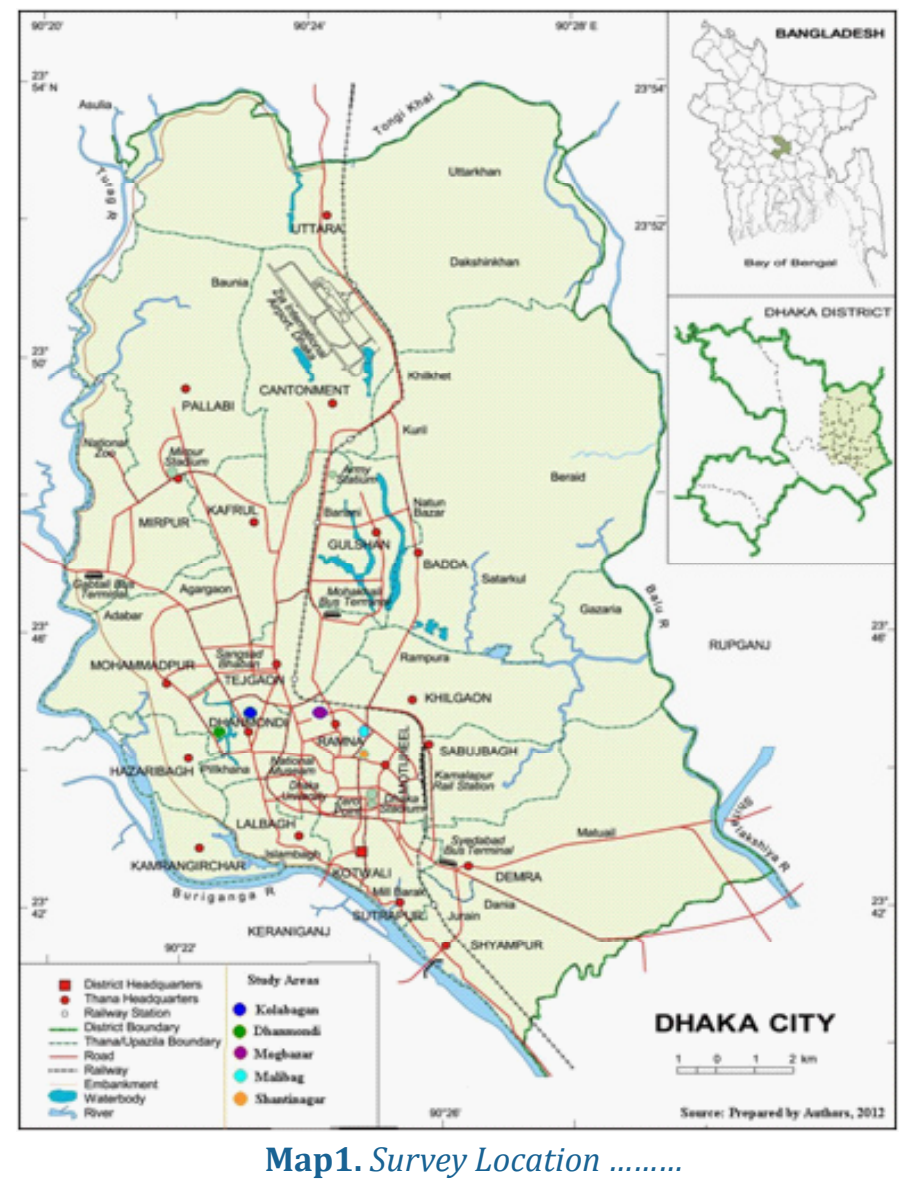

This study also uses the marginal propensity to consume and marginal propensity to save to examine the current situation of these vendors.

8. John Maynard Keynes, The General Theory of Employment, Interest and Money, Harcourt Brace Jovanovich, New York, 1936, p. 96. 
According to Keynesian, the consumption function is as following:

$$
\mathrm{Y}=\beta 1+\beta 2 \mathrm{X} ; \quad 0<\beta 2<1
$$

Where, $Y=$ consumption expenditure and $X=$ income, and $\beta 1$ and $\beta 2$, known as the parameters of the model, are, respectively, the intercept and slope coefficients.

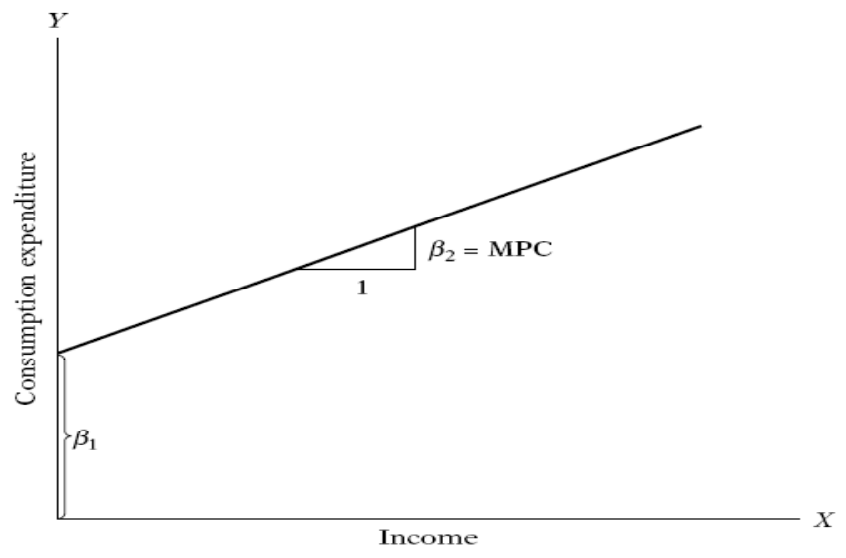

Fig1.1. Keynesian consumption function

The slope coefficient $\beta 2$ measures the MPC. Geometrically, the above equation is as shown in Figure 1.1. This equation, which states that consumption, is linearly related to income. If the model has only one equation, as in the preceding example, it is called a single-equation model, whereas if it has more than one equation, it is known as a multiple-equation model. This study considers the single equation model. In the equation, the variable appearing on the left side of the equality sign is called the dependent variable and the variable on the right side are called the independent or explanatory variable. Thus, in the Keynesian consumption function, consumption (expenditure) is the dependent variable and income is the explanatory variable.

This study tries to illustrate the current situation of the business informal sector of Dhaka city. To the simplicity, this study uses only 50 vendors of Dhaka city (South). All the 50 vendors were selected randomly from the Dhaka city (South) including the areas Dhanmondi, Kalabagan, Malibag, Mogbazar and Shantinagar.

Finally, this study tries to illustrate the distributions of income and their expenditure as well as savings of the 50 vendors of the informal sector of the Dhaka city (South). In addition, this study also illustrates the current situation of the vendors of the informal sector of Dhaka city (South).

\section{ANALYSIS AND Findings}

\section{Place of Birth}

Among the randomly selected 50 respondents, 8 vendors were from Rangpur, 8 from Bhola, 7 from Gaibandha, 6 from Dinajpur, 5 from Borguna, 4 from Mymensing and 2 respondents from each of Barisal, Cox's Bazar, Faridpur, Nawabgonj, Pubna and Rajshahi District.

\section{Gender}

Of the 50 respondents, 84 percent of the total vendors are male and 16 percent are female. According to the figure 2 , most of the vendors are male. This scenario also reflects the overall condition of city regions male-female ratio involved in business sector but the female ratio is low due to incapable to cope with the socio-cultural circumstances. 


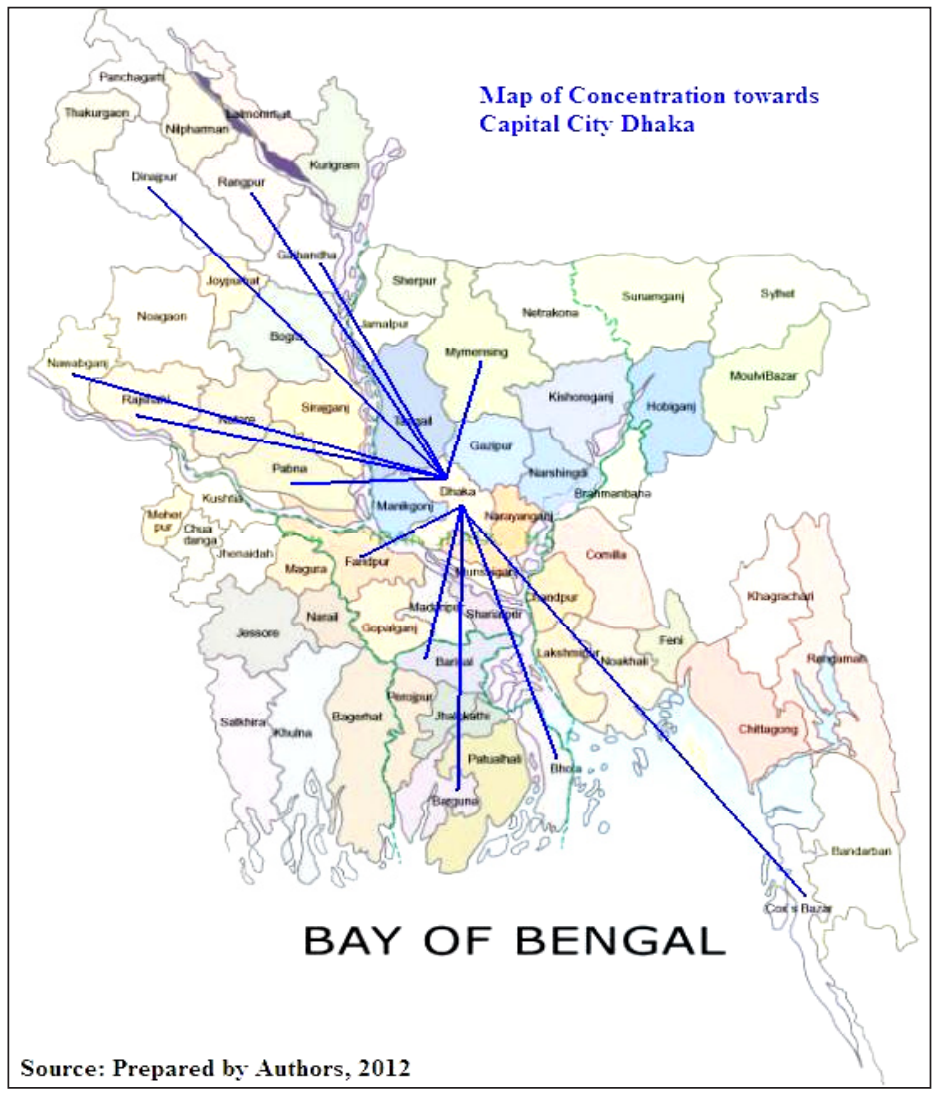

Map2. Origin of Vendors ..........

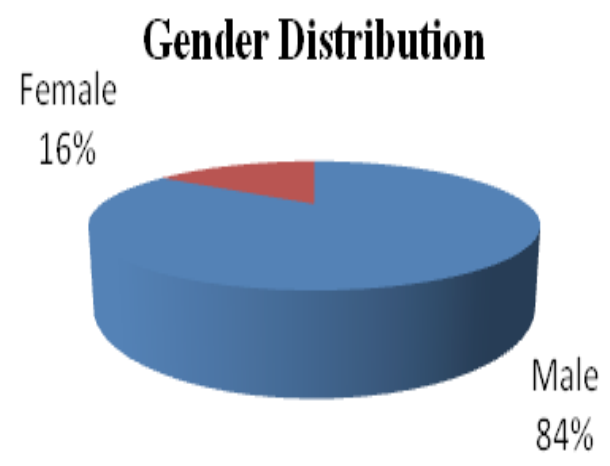

Fig1. Gender

\section{Marital Status}

There are 76 percent of the vendors are married, 16 percent are unmarried and 8 percent are widow. All the respondents either married or unmarried come to Dhaka for searching a new job to improve their standard of living by earning more money. They came after marriage and having or preparing to have children and to ensure their present and future safety and security. Again the unmarried come to earn and to save some money to support his/ her family. Married people feel much more secured than the unmarried in this profession; mainly the women. 


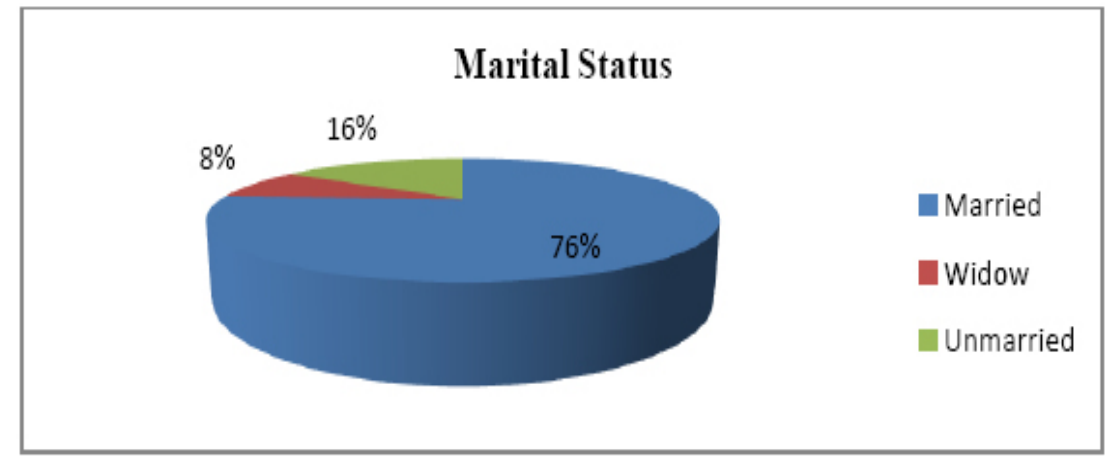

Fig2. Marital Status

\section{Religion}

There are 76 percent of Muslim and 24 percent are Hindu among the 50 vendors. So it can be said that religion is not the influencing factor of doing this profession it may be the other causes.

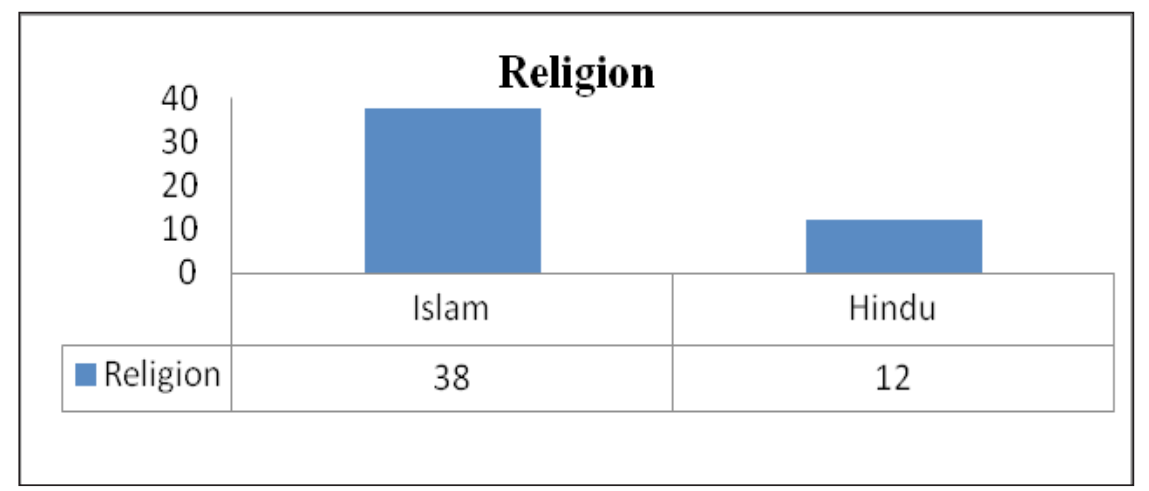

Fig3. Religion

\section{Family Status}

Bangladesh is a country of large population. Most of families were jointed but recently single family or nuclear family concept is widely spread and influenced. In our study we have find that 80 percent of the respondents' family is nuclear and only 20 percent of the respondents' family is joint. Dependency on single earning member from a single family derives the able person to get involved and migrate for earning. On the other hand, joint family members work together to meet up their family needs.

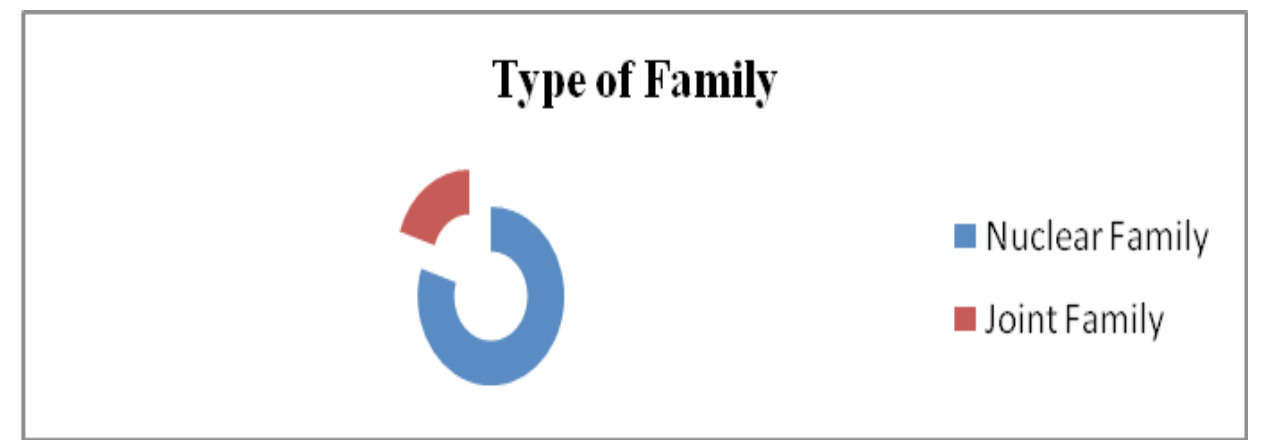

Fig4. Types of Family 


\section{Family Size}

Among the vendors, most of the family have large number of population. There are 34 percent of vendor's, each of the family have 4 members, 26 percent vendor's family have 5 members, 10 vendor's family have 3 members, 4 vendor's familly have 2 members, 4 vendor's family have 1 member and only 2 vendor's family have 6 members. So the average family size of the 50 vendors are 4 persons which is also the refleclection of our countries overall family size as well.

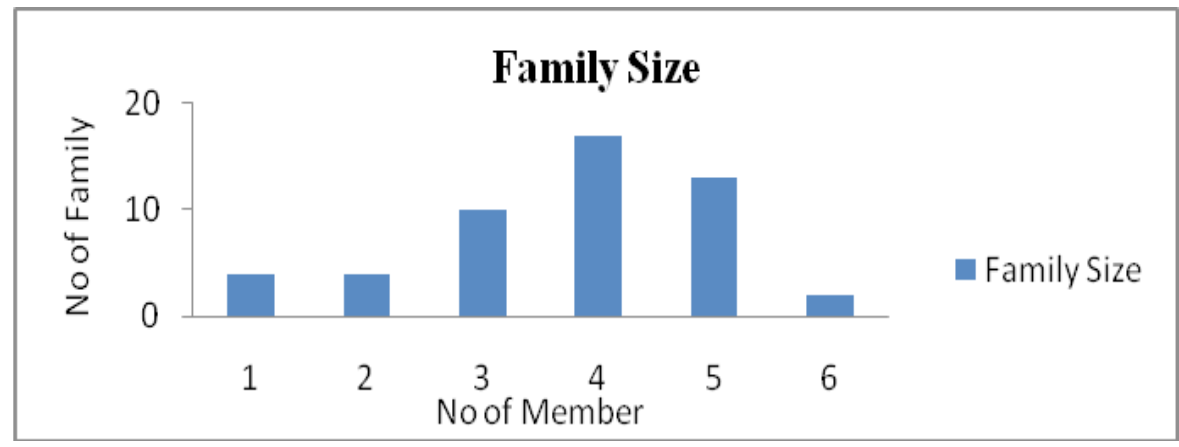

Fig5. Size of the Family

\section{Initial Investment}

The most significant impact shows in the initial investment. The trend of initial investment is downward sloping which implies that as the initial investment increases the number of vendor's decreases due to their inability. According to the study most of the vendors' initial investment lies between BDT 5,000 to BDT 9,000 and the numbers are 48 percent. The initial investment of the 32 percent of the vendor's lies between BDT 10,000 to BDT 14,000 and only 20 percent of the vendors' initial investment are above BDT 15,000 but not more than BDT 20,000. So it can be illustrated that the informal economy of the Dhaka City are small and they cannot expand their business as their profit margin is also small. They don't have any strong family support as well as any other third party assurance like Government institutions, financial institutions or any formal institutions to run their business. This study also illustrates that their average initial investment is only BDT 10,220 which is very small amount and really there is a lack of proper accumulation of capital and other resources as well.

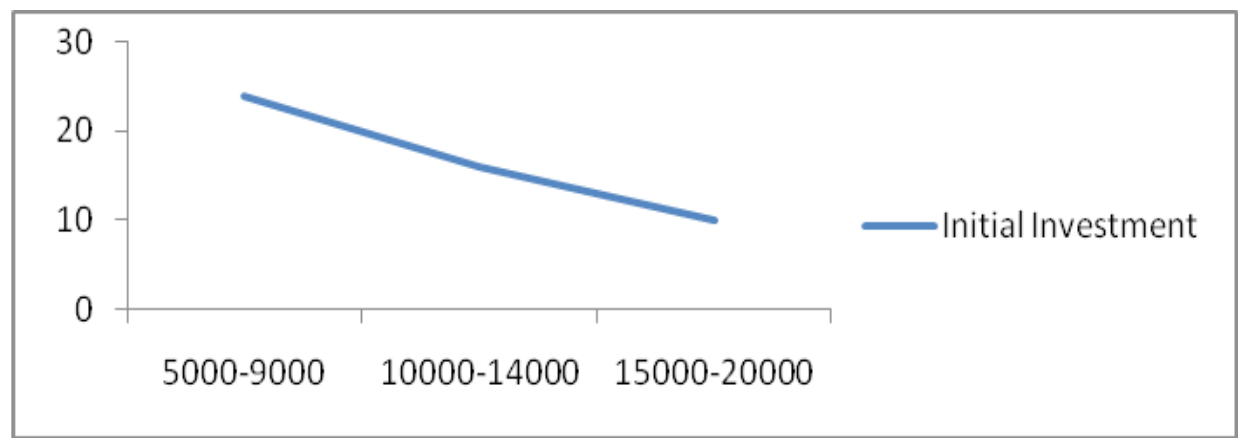

Fig6. Initial Investment

\section{Savings}

According to the figure 8 we see that average savings of the informal sector of Dhaka City (South) is BDT 896 which is very low in aspect of current situation. Because of increasing living cost in the capital city is high and there is less opportunity to save the money. Most of the vendors about 34 percent saved only between BDT 500 to BDT 999. 
Informal Economy of Dhaka City (South): Situation and Facts

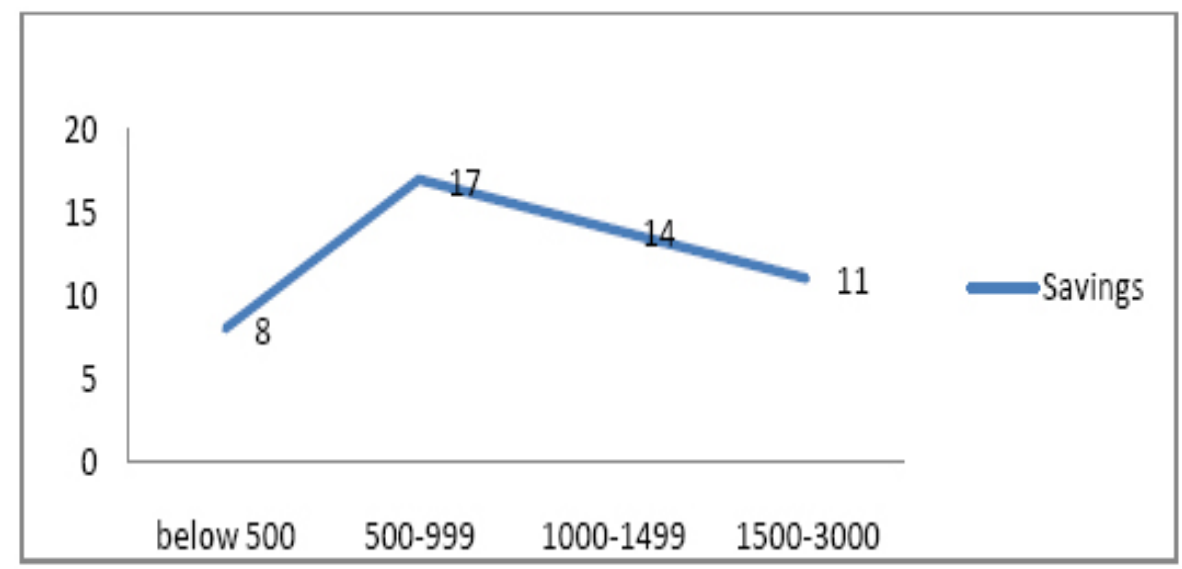

Fig7. Savings (monthly)

\section{ESTIMATION AND RESULTS}

\section{OLS Regression of Expenditure on Income of 50 Vendors}

Table1. OLS Regression Results of 50 Vendors of Informal Sector

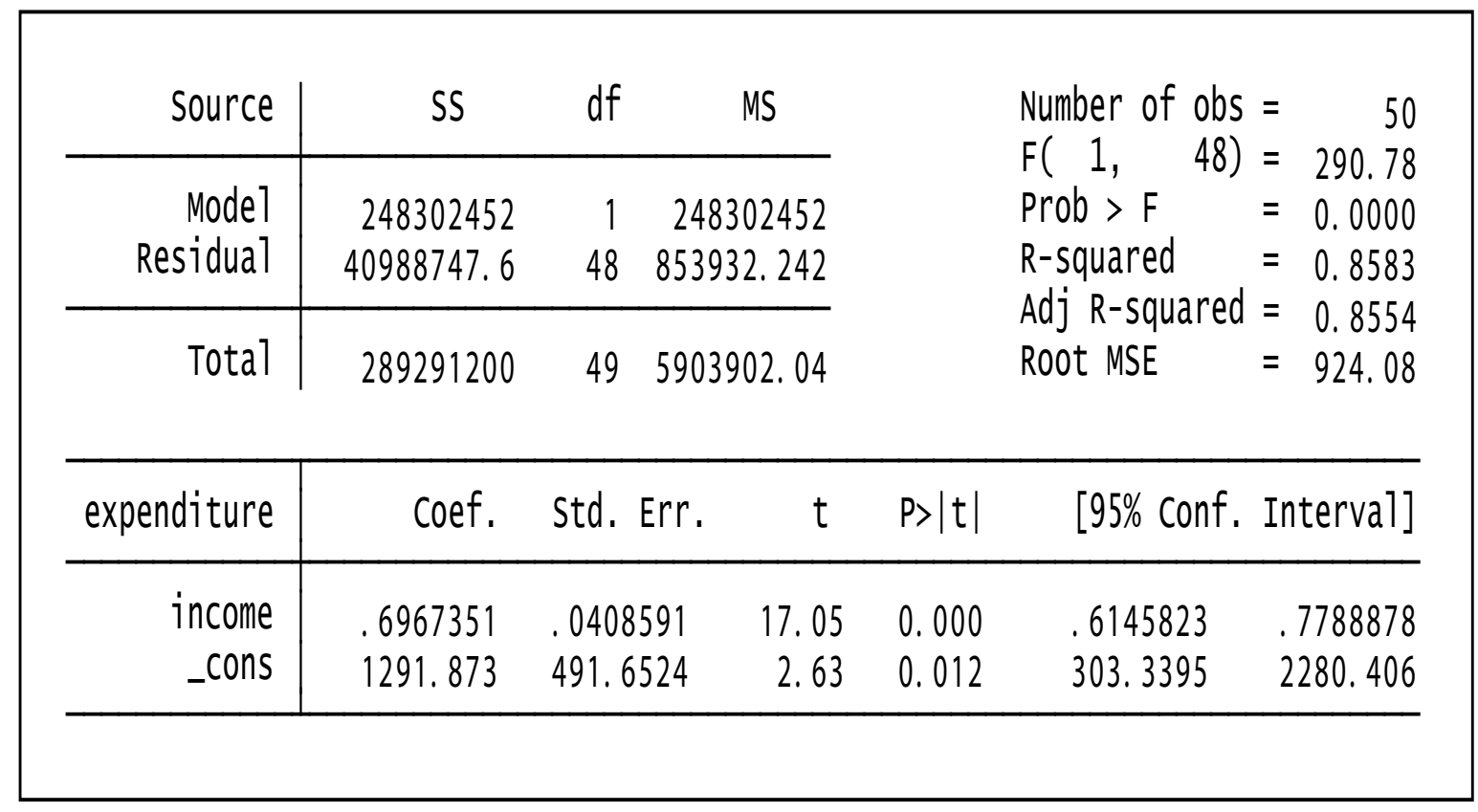

According to the table 1, OLS regression of the 50 vendors of the informal sector of Dhaka City shows that the estimation result is statistically significant as the $t$ value is 17.05 and its probability of $t$ value is 0.00 . The probability of $F$ distribution is 0.00 which also strengths the statement i.e. the result is statistically significant. Adjusted $R$ squared 0.85 i.e. the model is well fitted as the value of adjusted $R$ squared is 85 percent.

According to Keynes, marginal propensity to consume (MPC) of 50 vendors of the informal sector of Dhaka City is 0.697 which also known as the slope coefficient of income. So the marginal propensity to save (MPS) of 50 vendors of the informal sector of Dhaka City is:

$$
\text { MPS }=1-\mathrm{MPC}=1-0.697=0.303 .
$$


Informal Economy of Dhaka City (South): Situation and Facts

\section{OLS Regression of Expenditure on Income of 10 Vegetable Vendors}

Table2. OLS Regression Results Vegetable Vendors

\begin{tabular}{|c|c|c|c|c|c|c|c|}
\hline Source & SS & $d f$ & \multicolumn{2}{|c|}{ MS } & & \multirow{4}{*}{$\begin{array}{l}\text { Number of obs } \\
\text { F( 1, } \\
\text { Prob > } \quad 8) \\
\text { R-squared } \\
\text { Adj R-squared } \\
\text { Root MSE }\end{array}$} & \multirow{4}{*}{$\begin{array}{r}10 \\
27.97 \\
0.0007 \\
0.7776 \\
0.7498 \\
1138.6\end{array}$} \\
\hline Mode 1 & 36268820.8 & 1 & \multirow{2}{*}{\multicolumn{2}{|c|}{$\begin{array}{r}36268820.8 \\
1296522.4\end{array}$}} & & & \\
\hline Residual & 10372179.2 & 8 & & & & & \\
\hline Total & 46641000 & 9 & \multicolumn{2}{|c|}{5182333.33} & & & \\
\hline expenditure & Coef. & std. & Err. & $\mathrm{t}$ & $P>|t|$ & [95\% Conf. & Interva1] \\
\hline income & 6990232 & .1321 & 645 & 5. 29 & 0.001 & 3942513 & \multirow{2}{*}{$\begin{array}{l}1.003795 \\
4376.131\end{array}$} \\
\hline _cons & 1055.305 & 1440. & 078 & 0.73 & 0.485 & -2265.521 & \\
\hline
\end{tabular}

According to the table 2, OLS regression of the 10 vegetable vendors shows the estimation result is statistically significant as the $t$ value is 5.29 and its probability of $t$ value is 0.001 . The probability of $F$ distribution is 0.0007 which also strengths the statement i.e. the result is statistically significant. Adjusted $R$ squared 0.749 i.e. the model is well fitted as the value of adjusted $R$ squared is about 75 percent.

According to Keynes the marginal propensity to consume (MPC) of these 10 vegetable vendors is 0.699 which also known as the slope coefficient of income. So the marginal propensity to save of the 10 vegetable vendors is

$$
\mathrm{MPS}=1-\mathrm{MPC}=1-0.699=0.301
$$

\section{OLS Regression of Expenditure on Income of 10 Tea Vendors}

Table3. OLS Regression Results of Tea Vendors

\begin{tabular}{|c|c|c|c|c|c|c|c|}
\hline Source & SS & $d f$ & \multicolumn{2}{|c|}{ MS } & & \multirow{4}{*}{$\begin{array}{l}\text { Number of obs } \\
\text { F( 1, 8) } \\
\text { Prob }>\text { F } \\
\text { R-squared } \\
\text { Adj R-squared } \\
\text { Root MSE }\end{array}$} & \multirow{4}{*}{$\begin{array}{r}10 \\
53.78 \\
0.0001 \\
0.8705 \\
0.8543 \\
994.25\end{array}$} \\
\hline Model & 53161966.1 & 1 & \multirow{2}{*}{\multicolumn{2}{|c|}{$\begin{array}{l}53161966.1 \\
988535.489\end{array}$}} & & & \\
\hline Residual & 7908283.91 & 8 & & & & & \\
\hline Total & 61070250 & 9 & \multicolumn{2}{|c|}{6785583.33} & & & \\
\hline expenditure & Coef. & std. & Err. & $\mathrm{t}$ & $P>|t|$ & {$[95 \%$ Conf. I } & Interval] \\
\hline $\begin{array}{r}\text { income } \\
\text { _cons }\end{array}$ & $\begin{array}{l}.6277613 \\
2336.879\end{array}$ & $\begin{array}{l}.0856 \\
1148 .\end{array}$ & $\begin{array}{l}032 \\
169\end{array}$ & $\begin{array}{l}7.33 \\
2.04\end{array}$ & $\begin{array}{l}0.000 \\
0.076\end{array}$ & $\begin{array}{r}.4303599 \\
-310.8028\end{array}$ & $\begin{array}{r}.8251627 \\
4984.561\end{array}$ \\
\hline
\end{tabular}

According to the table 2, OLS regression of the 10 tea vendors shows the estimation result is statistically significant as the $t$ value is 7.33 and its probability of $t$ value is 0.000 . The probability of $F$ distribution is 0.0001 which also strengths the statement i.e. the result is statistically significant. Adjusted $R$ squared 0.85 i.e. the model is well fitted as the value of adjusted $R$ squared is about 85 percent.

According to Keynes the marginal propensity to consume (MPC) of these 10 tea vendors is 0.627 which also known as the slope coefficient of income. So the marginal propensity to save of the 10 tea vendors is

$$
\mathrm{MPS}=1-\mathrm{MPC}=1-0.627=0.373
$$


Informal Economy of Dhaka City (South): Situation and Facts

\section{OLS Regression of Expenditure on Income of 10 Fuska vendors}

Table4. OLS Regression Results of Fuska Vendors

\begin{tabular}{|c|c|c|c|c|c|c|c|}
\hline Source & SS & $d f$ & \multicolumn{2}{|c|}{ MS } & & \multirow{4}{*}{\multicolumn{2}{|c|}{$\begin{array}{lr}\text { Number of obs } & = \\
\mathrm{F}(1, \quad 8) & =30.15 \\
\text { Prob }>\mathrm{F} & =0.0006 \\
\text { R-squared } & =0.7903 \\
\text { Adj R-squared } & =0.7641 \\
\text { Root MSE } & =821.27\end{array}$}} \\
\hline Model & 20336333.3 & 1 & \multirow{2}{*}{\multicolumn{2}{|c|}{$\begin{array}{l}20336333.3 \\
674489.583\end{array}$}} & & & \\
\hline Residual & 5395916.67 & 8 & & & & & \\
\hline Total & 25732250 & 9 & \multicolumn{2}{|c|}{2859138.89} & & & \\
\hline expenditure & coef. & std. & Err. & $\mathrm{t}$ & $P>|t|$ & {$[95 \%$ Conf. $]$} & Interval] \\
\hline income & 8233333 & .1499 & 433 & 5.49 & 0.001 & .4775635 & 1. 169103 \\
\hline _cons & 175 & 1817. & & 0.10 & 0.926 & -4017.236 & 4367.236 \\
\hline
\end{tabular}

According to the table 2, OLS regression of the 10 fuska vendors shows the estimation result is statistically significant as the $t$ value is 5.49 and its probability of $t$ value is 0.001 . The probability of $F$ distribution is 0.0006 which also strengths the statement i.e. the result is statistically significant. Adjusted $R$ squared 0.76 i.e. the model is well fitted as the value of adjusted $R$ squared is about 76 percent.

According to Keynes the marginal propensity to consume (MPC) of these 10 fuska vendors is 0.823 which also known as the slope coefficient of income. So the marginal propensity to save of the 10 fuska vendors is

$$
\text { MPS = 1- MPC }=1-0.823=0.177
$$

\section{OLS Regression of Expenditure on Income of 10 Fruit Vendors}

Table4. OLS Regression Results of Fruit Vendors

\begin{tabular}{|c|c|c|c|c|c|c|c|}
\hline Source & SS & $d f$ & \multicolumn{2}{|c|}{ MS } & & \multirow{4}{*}{$\begin{array}{l}\text { Number of obs } \\
\text { F( } 1, \\
\text { Prob }>\mathrm{F} \\
\text { R-squared } \\
\text { Adj R-squared } \\
\text { Root MSE }\end{array}$} & \multirow{4}{*}{$\begin{array}{r}10 \\
36.68 \\
0.0003 \\
0.8209 \\
0.7986 \\
984.74\end{array}$} \\
\hline Model & 35566243.2 & 1 & \multirow{2}{*}{\multicolumn{2}{|c|}{$\begin{array}{l}35566243.2 \\
969719.603\end{array}$}} & & & \\
\hline Residual & 7757756.82 & 8 & & & & & \\
\hline Total & 43324000 & 9 & \multicolumn{2}{|c|}{4813777.78} & & & \\
\hline expenditure & Coef. & std. & Err. & $\mathrm{t}$ & $P>|t|$ & [95\% Conf. & Interval] \\
\hline income & 6922196 & .114 & 005 & 6.06 & 0.000 & 4286423 & \multirow{2}{*}{$\begin{array}{r}9557969 \\
3909.048\end{array}$} \\
\hline _cons & 1037.083 & 1245 & & 0.83 & 0.429 & -1834.882 & \\
\hline
\end{tabular}

According to the table 4, OLS regression of the 10 fruit vendors shows the estimation result is statistically significant as the $t$ value is 6.06 and its probability of $t$ value is 0.000 . The probability of $F$ distribution is 0.0003 which also strengths the statement i.e. the result is statistically significant. Adjusted $R$ squared 0.798 i.e. the model is well fitted as the value of adjusted $R$ squared is about 80 percent.

According to Keynes the marginal propensity to consume (MPC) of these 10 fruit vendors is 0.692 which also known as the slope coefficient of income. So the marginal propensity to save of the 10 fruit vendors is

MPS = 1- MPC = 1- $0.692=0.308$ 
Informal Economy of Dhaka City (South): Situation and Facts

OLS Regression of Expenditure on Income of 10 Mixed Vendors

Table5. OLS Regression Results of Mixed Vendors

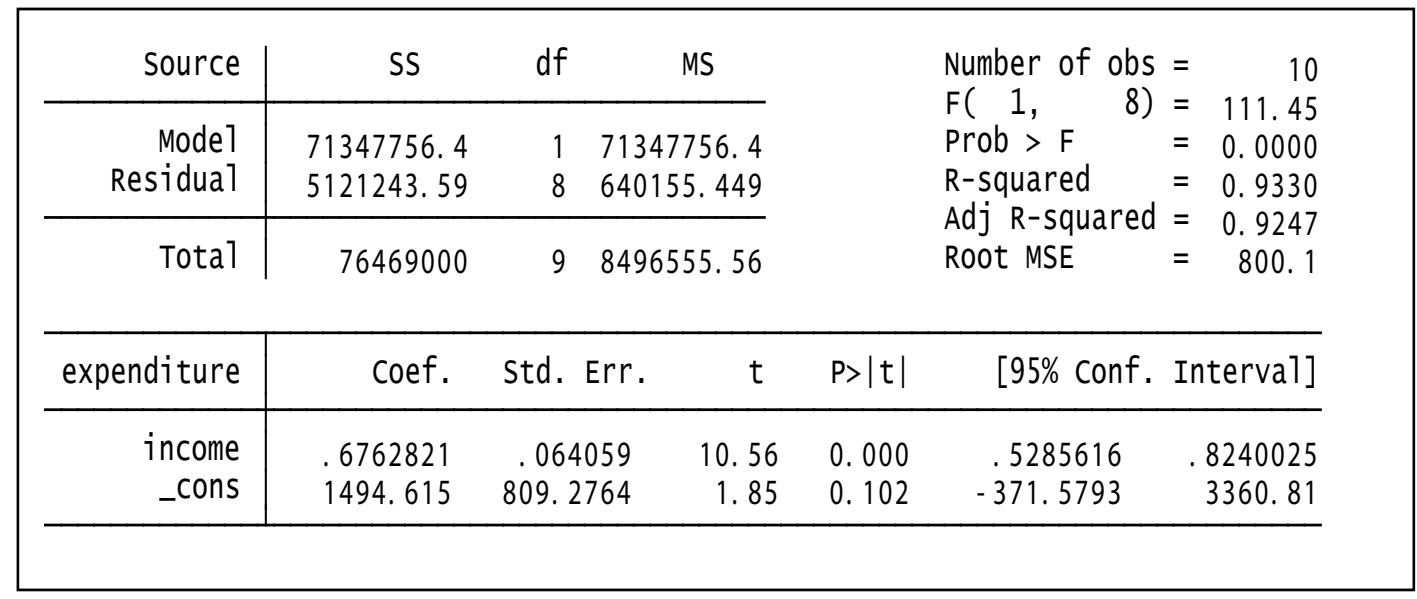

According to the table 5, OLS regression of the 10 mixed vendors shows the estimation result is statistically significant as the $t$ value is 10.56 and its probability of $t$ value is 0.000 . The probability of $F$ distribution is 0.000 which also strengths the statement i.e. the result is statistically significant. Adjusted $R$ squared 0.92 i.e. the model is well fitted as the value of adjusted $R$ squared is about 92 percent.

According to Keynes the marginal propensity to consume (MPC) of these 10 mixed vendors is 0.676 which also known as the slope coefficient of income. So the marginal propensity to save of the 10 mixed vendors is

$$
\mathrm{MPS}=1-\mathrm{MPC}=1-0.676=0.324
$$

\section{Overall Findings}

After studying and analyzing all the related aspects and also clear that the informal business directly or indirectly influences the people to migrate for employment or to income to lead their family. Initial investment, the most significant factor, persuades the earning which is not sufficient enough to improve their situation. As a result, they have to lead their own business with limited profits. Again, with this low and limited ability to invest it is hard for them to increase the amount of savings after accomplishing most of their desired demand in the costly Capital City. According to the study we have find the significant impact of the consumption and expenditure which is also illustrated by the MPC and MPS. In the continuation of these low profit or low savings, the trend of initial investment of the no of vendors become downward as it increases the amount. Sometimes these vendors are relocated due to city management authorities or chadabaj's torture. They are instable for a particular time in a single place. They have to pay a good amount of bribe to the local leader or to the duty police. Even sometimes their money is grabbed by the addicted persons. Scarcely had they got any kind of support from the security authority. Different ruling Government takes different initiative to relocate, support but only for short period of time.

Findings includes:

- Informal employment dominates the country's labor market as well as Dhaka Coty (South), being estimated at about $65 \%$ of the total number of jobs, with female reporting a higher incidence.

- However, informal workers are occasionally disadvantaged comparing with formal workers, particularly in terms of income and social protection coverage

- $\quad$ Therefore, informal workers are more vulnerable to economic and social shocks 
Informal Economy of Dhaka City (South): Situation and Facts

- Informal enterprises need more access to loans and technical training and modern machineries

- Comprehensive, detailed and up-to-date information about the informal sector and informal economy are needed such data is required to paint a clearer image of the state of the labor market, access to various social protection mechanisms, and the circumstances of the informal enterprises.

\section{RECOMMENDATION AND CONCLUSION}

\section{Recommendation}

The phenomenon of informal economic activity has become something studied by many researchers, both governmental and nongovernmental. In authors view, this research has consisted of an important domain of the informal sector of Dhaka city (South).

In light of the manifold appearances of the informal sector and consequently the variety of criteria describing each of them and the sum of all activities will provide a picture of the informal sector as a whole.

The informal sector is a dynamic phenomenon, which might have a significant impact in the economy. In light of the general poverty, low technology and development, informal activities are often considered as an economic, political and social value for public discontent. Nevertheless, transformation in the long run is a necessity for these countries as well.

There is a difference observed between the informal sector in developed and less developed countries, is that the informal sector in developed countries shows possibilities for accumulation and a comparable standard of income with the formal sector. Instead, the informal sector in less developed countries is identified with low income and little if any accumulation capacity. The main difference is related to the modes of production. Accordingly, technological dynamism (technological innovation and accumulation) characterizes, to a large extent, the informal sector in developed countries, while low technology and survival mechanisms characterize the informal sector in less developed countries. However, a better understanding of why the informal sector exists and what is its relationship to the formal sector needs further research as well as the government should take some measures to regulate and facilitate of this sector because day by day the density of the city is increasing at an alarming rate. The demand for basic needs is unending. So far to make the informal sector partially legal, to regulate, to earn revenue government and city management authority have to take prudent decision for better civic life and overall development.

\section{Conclusion}

Informal economy of Dhaka City (South) is not a deviation of the formal economy, if only because all economic activities started informal and formed the basis from which the formal economy sprang, with firms and annual accounts, taxes, chambers of commerce etc. Obviously, there are several criteria which can be used to describe the diverse forms of the appearance of the informal sector. Both the existences of these various forms and several criteria yield the big variety in definitions. Understandably, the existence of a variety of descriptions/ definitions is confusing, as Renooy (1990) has pointed out. In addition, this large variety of definitions makes it difficult to provide a uniform picture of the field. However, consensus amongst the authors about what is being studied has grown.

There is basically agreement in both groups of studies (about developed and less developed countries) regarding the use of the classic criteria - undeclared labor, tax evasion, unregulated or unlicensed enterprises, illegality or criminality - in defining the informal sector. Besides some slight differences concerning the 'national statistics' and 'professional status' criteria, the basic divergence among these groups of studies is related to the 'survival' criterion. Contrary to research on the informal sector in less developed countries, some studies of the informal sector in developed countries have shown that the informal sector offers possibilities for accumulation. 
To sum up, the previously mentioned studies have contributed to the general thought that the informal economy is not a homogeneous phenomenon, but a much diversified one. Therefore, any attempt to study it as a whole (including the introduction of a precise broad definition) cannot be completely successful. This does not mean that any effort should be discouraged or not supported. In my view, definitions of the informal sector can vary across countries, bearing in mind the political, economic, cultural and social differences. However, the differences seem to be strongest between developed and undeveloped countries.

\section{STUDY LiMitaTions}

Limitations of the study are as following:

- Firstly, 50 respondents were too small a sample to conduct an economic analysis to the national perspective.

- Secondly, gauging cultural status was very difficult and in most cases the respondents avoided them.

- Thirdly, And lastly, it was difficult to interview the vendors during their business hours and some did bother to answer the questions with importance. This was possibly due to trust issues.

\section{REFERENCES}

Alford, R.R., and Feige, E.L., 1989. "Information Distortions in Social Systems: The Underground Economy and other Observer-Subject-Policymaker Feedbacks" in Feige (eds.), The Underground Economy: Tax Evasion and Information Distortion, Cambridge University Press, pp. 57-81.

Allingham, M.G., and Sandmo, A., 1972. "Income Tax Evasion: A Theoretical Journal of Public Economics, vol. 1, pp. 323-38.

Anderson, J.H., 1998. “The Size, Origins, and Character of Mongolia's Informal Sector World Bank WP 1916.

Becker, G.S., 1976. The Economic Approach to Human Behavior, University of Chicago Press, Chicago and London.

Blau, P.M. and Scott, W.R, 1963. Formal Organizations: A Comparative Approach, London, Routledge and Kegan Paul.

Boeke, J.H., 1953. Economics and Economic Policy of Dual Societies, New York.

Breman, J.C., 1980. The Informal Sector In Research: Theory And Practice, casp 3, Rotterdam.

Bromley, R. and Gerry, C. (eds.), 1979. "Casual Work and Poverty in Third World Chichester, Wiley and Sons.

Cagan, P., 1958. 'The Demand for Currency Relative to the Total Money Supply, Journal of Political Economy, 66, pp. 303-328.

Commander, S. and Tolstopiatenko A., 1997. 'A Model of the Informal Economy in Transition Economies'. WP 122. The William Davidson Institute (University of Michigan).

Feige, E.L., 1981. "The UK's Unobserved Economy: A Preliminary Assessment", Journal of Economic Affairs, vol. 1, pp. 205-12.

Feige, E.L., 1989. The Underground Economies: Tax Evasion and Information Distortion (ed.), Cambridge University Press.

Fortuna, J.C., and Prates, S., 1989. "Informal Sector versus Informalized Labor Relations in Uruguay", in Portes, A., Castells, M., and Benton, L.A., The Informal

Economy: Studies in Advanced and Less Developed Countries, Baltimore, Johns Hopkins. 
Informal Economy of Dhaka City (South): Situation and Facts

Frey, B.S., 1989. "How Large (or Small) should the Underground Economy

Feige (eds.), The Underground Economy: Tax Evasion and Information

Distortion, Cambridge University Press, pp. 111-29.

Gaddy, C., and Ickes, B.W., 1998. "To Restructure or Not to Restructure: Informal Activities and Enterprise Behavior in Transition", WP 134, The William Davidson Institute at the University of Michigan Business School.

Geertz, 1963. "Peddlers and Princes: Social Change and Economic Modernization in Two Indonesian Towns, Chicago, University of Chicago.

Gershuny, J.I., 1979. "The Informal Economy: Its Role in Post-Industrial Society”, Futures. Vol. 11, pp. 3-15.

Guerguil, M, 1988. "Some Thoughts on the Definition of the Informal Sector". CEPAL Review, 35, pp. 57-65.

Gutmann, P.M., 1977. “The Subterranean Economy”, Financial Analysis Journal, 33 (6), pp. 26-27, 34.

Hansson, I., 1989. "The Underground Economy in Sweden", in Feige (eds.), The Underground Economy: Tax Evasion and Information Distortion, Cambridge University Press, pp. 219-37.

Harding, P. and Jenkins, R., 1989. The Myth of the Hidden Economy: Towards a New Understanding of Informal Economic Activity, Open University Press, Milton Keynes, Philadelphia.

Hart, K., 1973. "Informal Income Opportunities and Urban Employment in Ghana", Journal of Modern African Studies, 11, 1, pp 61-89.

Internal Revenue Service (IRS), 1979. Estimates of Income Unreported on Individual Income Tax Returns, Washington DC: Government Printing Office.

International Labor Office (ILO), 1972. “Employment, Income and Equality: A Strategy for Increasing Productivity in Kenya". Geneva.

Islam, A Z M Shafiqul. Solid Waste management in Dhaka City, Dhaka City Corporation.

Kaufmann, D. and Kaliberda, A., 1996. "Integrating the Unofficial Economy into the Dynamics of Post-Socialist Economies: A Framework of Analysis and Evidence", Mimeo, World Bank.

Kolm, S.C., 1973. "A Note on Optimum Tax Evasion", Journal of Public Economics, vol. 2, pp. 265-70.

Lacko`, M., 1999. Hidden Economy - An Unknown Quantity? Comparative Analysis of Hidden Economies in Transition Countries in 1989-1995. WP 9905.

Lubell, H., 1991. "The Informal Sector in the 1980s and 1990s". Paris: OECD.

Macafee, K., 1980. "A Glimpse of the Hidden Economy in the National Accounts", Economic Trends, vol. 316, pp. 81-87 (also in Tanzi (ed.) 1982). Mattera, P., 1985. Off the Books, London, Pluto Press.

Portes, A., Castells, M., and Benton, L. A., (eds.) 1989. The Informal Economy: Studies in Advanced and Less Developed Countries, Baltimore, Johns Hopkins University Press.

Parvin Khaleda, Vendors start occupying footpaths ahead of Eid, New Age, 25th September 2006.

Profile of Dhaka City Corporation, Published by Urban Planning Department DCC, April 2004

Ramsay, F.R., 1927. "A Contribution to the Theory of Taxation", Economic Journal, vol. 37, pp. 47-61.

Renooy, P.H., 1990. The Informal Economy: Meaning, Measurement and Social Significance. Netherlands Geographical Studies, Amsterdam. 
Informal Economy of Dhaka City (South): Situation and Facts

Sabel, C.F., 1982. Work and Politics, Cambridge University Press, Cambridge.

Sandmo, A., 1981. 'Income Tax Evasion, Labor Supply and the Equity-Efficiency Journal of Public Economics, vol. 16, pp. 265-88.

Schneider, F., 1997. "Empirical Results for the Size of the Shadow Economy of Western European Countries over Time". Johannes Kepler University of Linz, Arbeitspaper: 9710.

Sethuraman, S.V., 1976. "The Urban Informal Sector: Concept, Measurement and International Labor Review, 114,1, pp 69-81.

Singh, B., 1973. "Making Honesty the Best Policy", Journal of Public Economics, vol. 2, pp. 257-63.

Smithies, E., 1984. The Black Economy in England since 1914, Gill and Macmillan, Dublin.

Srinivasan, T.N., 1973. “Tax Evasion: A Model”, Journal of Public Economics, pp. 339-46.

Stedman Jones, G., 1984. Outcast London, revised edition, Harmonds-worth, Peregrine.

Swaminathan, M., 1991. 'Understanding The 'Informal Sector': A Survey'. WP 95.WIDER, Finland.

Tanzi, V., 1982. The Underground Economy in the United States and Abroad (ed.), D.C Heath and Co. Lexington, Massachusetts, Toronto.

Tucker, M., 1982. "The Underground Economy in Australia" in Tanzi (eds.) The Underground Economy in the United States and Abroad, Lexington, Mass., D.C. Heath.

\section{Annex}

Annex A: Data set 1

\begin{tabular}{|c|c|c|c|c|c|c|c|c|c|}
\hline $\begin{array}{c}\text { Sl } \\
\text { No }\end{array}$ & age & $\begin{array}{c}\text { male }=1 \\
\text { female }=0\end{array}$ & $\begin{array}{c}\text { married }=1 \\
\text { unmarried=2 } \\
\text { divorced/ } \\
\text { widow }=3\end{array}$ & $\begin{array}{l}\text { religion } \\
\text { Islam=1 } \\
\text { Hindu=2 }\end{array}$ & $\begin{array}{c}\text { Origin } \\
\text { (District) }\end{array}$ & $\begin{array}{c}\text { family } \\
\text { nuclear }=1 \\
\text { joint=2 } \\
\text { others=3 }\end{array}$ & $\begin{array}{c}\text { family } \\
\text { members }\end{array}$ & occupation & $\begin{array}{c}\text { working } \\
\text { hours } \\
\text { per day }\end{array}$ \\
\hline 1 & 26 & 1 & 1 & 2 & Borguna & 1 & 3 & tea & 8 \\
\hline 2 & 35 & 1 & 1 & 1 & Rangpur & 1 & 5 & veg & 10 \\
\hline 3 & 35 & 1 & 1 & 2 & Gaibandha & 1 & 4 & tea & 10 \\
\hline 4 & 25 & 1 & 1 & 2 & Mymensing & 1 & 2 & veg & 9 \\
\hline 5 & 22 & 1 & 2 & 2 & Vola & 2 & 4 & tea & 10 \\
\hline 6 & 45 & 1 & 1 & 1 & Rangpur & 1 & 5 & veg & 9 \\
\hline 7 & 23 & 1 & 2 & 1 & Dinajpur & 1 & 1 & veg & 8 \\
\hline 8 & 27 & 1 & 1 & 1 & Borguna & 2 & 5 & tea & 9 \\
\hline 9 & 43 & 0 & 1 & 1 & Dinajpur & 2 & 8 & tea & 9 \\
\hline 10 & 40 & 0 & 3 & 1 & Rangpur & 1 & 3 & tea & 10 \\
\hline 11 & 42 & 1 & 1 & 1 & Rangpur & 1 & 4 & tea & 10 \\
\hline 12 & 28 & 1 & 1 & 1 & Vola & 1 & 3 & tea & 8 \\
\hline 13 & 40 & 1 & 1 & 2 & Faridpur & 1 & 4 & fruit & 9 \\
\hline 14 & 35 & 1 & 1 & 1 & Pubna & 2 & 6 & fuska & 8 \\
\hline 15 & 30 & 1 & 1 & 1 & Dinajpur & 1 & 3 & tea & 12 \\
\hline
\end{tabular}


Informal Economy of Dhaka City (South): Situation and Facts

\begin{tabular}{|c|c|c|c|c|c|c|c|c|c|}
\hline $\begin{array}{c}\text { Sl } \\
\text { No }\end{array}$ & age & $\begin{array}{c}\text { male }=1 \\
\text { female }=0\end{array}$ & $\begin{array}{c}\text { married=1 } \\
\text { unmarried=2 } \\
\text { divorced/ } \\
\text { widow=3 }\end{array}$ & $\begin{array}{c}\text { religion } \\
\text { Islam=1 } \\
\text { Hindu=2 }\end{array}$ & $\begin{array}{c}\text { Origin } \\
\text { (District) }\end{array}$ & $\begin{array}{c}\text { family } \\
\text { nuclear=1 } \\
\text { joint=2 } \\
\text { others=3 }\end{array}$ & $\begin{array}{c}\text { family } \\
\text { members }\end{array}$ & occupation & $\begin{array}{c}\text { working } \\
\text { hours } \\
\text { per day }\end{array}$ \\
\hline 16 & 38 & 1 & 1 & 1 & Rajshahi & 1 & 5 & fuska & 5 \\
\hline 17 & 40 & 1 & 1 & 1 & Barishal & 1 & 4 & fruit & 9 \\
\hline 18 & 30 & 1 & 1 & 1 & Nawabgonj & 2 & 5 & fruit & 9 \\
\hline 19 & 30 & 1 & 1 & 1 & Cox's Bazar & 1 & 3 & veg & 10 \\
\hline 20 & 22 & 1 & 2 & 1 & Vola & 1 & 1 & veg & 8 \\
\hline 21 & 26 & 1 & 2 & 2 & Vola & 1 & 4 & tea & 8 \\
\hline 22 & 38 & 0 & 3 & 1 & Mymensing & 1 & 4 & fuska & 8 \\
\hline 23 & 36 & 1 & 1 & 1 & Gaibandha & 1 & 5 & veg & 12 \\
\hline 24 & 29 & 1 & 1 & 1 & Gaibandha & 1 & 4 & veg & 8 \\
\hline 25 & 29 & 1 & 2 & 2 & Vola & 2 & 4 & veg & 8 \\
\hline 26 & 27 & 0 & 2 & 1 & Vola & 1 & 1 & veg & 8 \\
\hline 27 & 34 & 1 & 2 & 1 & Dinajpur & 1 & 1 & fruit & 8 \\
\hline 28 & 35 & 1 & 1 & 2 & Mymensing & 1 & 2 & fruit & 9 \\
\hline 29 & 32 & 1 & 1 & 2 & Borguna & 1 & 3 & fruit & 8 \\
\hline 30 & 43 & 1 & 2 & 2 & Vola & 1 & 4 & fruit & 8 \\
\hline 31 & 28 & 0 & 1 & 1 & Borguna & 2 & 5 & fruit & 9 \\
\hline 32 & 35 & 1 & 1 & 1 & Vola & 1 & 3 & fruit & 8 \\
\hline 33 & 36 & 1 & 1 & 1 & Gaibandha & 1 & 4 & fruit & 8 \\
\hline 34 & 39 & 1 & 1 & 1 & Dinajpur & 1 & 3 & fuska & 12 \\
\hline 35 & 38 & 1 & 1 & 1 & Nawabgonj & 2 & 5 & fuska & 9 \\
\hline 36 & 42 & 1 & 1 & 1 & Cox's Bazar & 1 & 3 & fried food & 10 \\
\hline 37 & 27 & 1 & 1 & 1 & Rangpur & 1 & 5 & fried food & 10 \\
\hline 38 & 25 & 1 & 1 & 2 & Gaibandha & 1 & 4 & fuska & 10 \\
\hline 39 & 31 & 1 & 1 & 1 & Pubna & 2 & 6 & fuska & 8 \\
\hline 40 & 36 & 1 & 1 & 1 & Gaibandha & 1 & 5 & fuska & 12 \\
\hline 41 & 30 & 1 & 1 & 1 & Rajshahi & 1 & 5 & fuska & 5 \\
\hline 42 & 38 & 0 & 3 & 1 & Mymensing & 1 & 4 & Ruti bhagi & 8 \\
\hline 43 & 30 & 0 & 3 & 1 & Rangpur & 1 & 3 & fuska & 10 \\
\hline 44 & 40 & 1 & 1 & 2 & Faridpur & 1 & 4 & Ruti bhagi & 9 \\
\hline 45 & 31 & 1 & 1 & 1 & Barishal & 1 & 4 & fried food & 9 \\
\hline 46 & 33 & 1 & 1 & 1 & Rangpur & 1 & 4 & jhalmuri & 10 \\
\hline 47 & 33 & 0 & 1 & 1 & Dinajpur & 2 & 8 & fried food & 9 \\
\hline 48 & 32 & 1 & 1 & 1 & Rangpur & 1 & 5 & jhalmuri & 9 \\
\hline 49 & 33 & 1 & 1 & 1 & Gaibandha & 1 & 4 & jhalmuri & 12 \\
\hline 50 & 30 & 1 & 1 & 1 & Borguna & 1 & 5 & jhalmuri & 8 \\
\hline
\end{tabular}


Informal Economy of Dhaka City (South): Situation and Facts

\section{Annex B: Data set 2}

\begin{tabular}{|c|c|c|c|c|c|c|c|c|c|}
\hline $\begin{array}{l}\text { Sl } \\
\text { No }\end{array}$ & $\begin{array}{l}\text { initial } \\
\text { investment }\end{array}$ & Income & Expenditure & $\begin{array}{l}\text { other } \\
\text { occupation }\end{array}$ & $\begin{array}{l}\text { payment } \\
\text { business } \\
\text { purpose }\end{array}$ & savings & borrowings & asset & tobacco \\
\hline 1 & 15000 & 10000 & 8100 & 0 & 400 & 500 & 0 & 70500 & 400 \\
\hline 2 & 10000 & 13000 & 11200 & 0 & 900 & 700 & 1 & 79000 & 300 \\
\hline 3 & 8000 & 12000 & 11600 & 0 & 200 & 0 & 0 & 58000 & 400 \\
\hline 4 & 9000 & 10000 & 8300 & 0 & 600 & 0 & 0 & 58000 & 300 \\
\hline 5 & 15000 & 17000 & 11600 & 0 & 700 & 2000 & 0 & 21000 & 400 \\
\hline 6 & 9000 & 10000 & 9500 & 0 & 0 & 0 & 1 & 12400 & 300 \\
\hline 7 & 10000 & 8000 & 4600 & 0 & 400 & 2000 & 0 & 13500 & 300 \\
\hline 8 & 20000 & 14000 & 12000 & 0 & 1000 & 1000 & 0 & 25700 & 300 \\
\hline 9 & 6000 & 21000 & 15900 & 0 & 900 & 1500 & 0 & 78000 & 350 \\
\hline 10 & 5000 & 14000 & 10350 & 0 & 900 & 0 & 1 & 20000 & 300 \\
\hline 11 & 5000 & 12000 & 10100 & 0 & 900 & 500 & 0 & 88200 & 300 \\
\hline 12 & 6000 & 8000 & 7500 & 0 & 200 & 500 & 1 & 21500 & 500 \\
\hline 13 & 8000 & 17000 & 11800 & 0 & 500 & 3000 & 0 & 76000 & 400 \\
\hline 14 & 12000 & 14000 & 11600 & 0 & 500 & 1000 & 0 & 63500 & 400 \\
\hline 15 & 5000 & 12000 & 10200 & 0 & 700 & 1000 & 0 & 50500 & 350 \\
\hline 16 & 12000 & 12000 & 10400 & 0 & 1500 & 500 & 1 & 67000 & 400 \\
\hline 17 & 10000 & 10000 & 8000 & 0 & 500 & 500 & 0 & 88200 & 200 \\
\hline 18 & 15000 & 11000 & 8800 & 0 & 0 & 500 & 0 & 19000 & 400 \\
\hline 19 & 13000 & 12000 & 9600 & 0 & 500 & 1000 & 1 & 98700 & 300 \\
\hline 20 & 8000 & 8000 & 6300 & 0 & 500 & 1500 & 0 & 11500 & 300 \\
\hline 21 & 12000 & 9000 & 7000 & 0 & 300 & 1000 & 0 & 25000 & 0 \\
\hline 22 & 8000 & 8000 & 6000 & 0 & 250 & 1000 & 0 & 30000 & 0 \\
\hline 23 & 13000 & 11000 & 9600 & 0 & 400 & 1000 & 0 & 40000 & 500 \\
\hline 24 & 15000 & 8500 & 7300 & 0 & 300 & 800 & 0 & 35000 & 0 \\
\hline 25 & 15000 & 17000 & 11600 & 0 & 700 & 2000 & 0 & 21000 & 400 \\
\hline 26 & 8000 & 8000 & 6300 & 0 & 500 & 1500 & 0 & 11500 & 300 \\
\hline 27 & 10000 & 8000 & 4600 & 0 & 400 & 2000 & 0 & 13500 & 300 \\
\hline 28 & 9000 & 10000 & 8300 & 0 & 600 & 0 & 0 & 58000 & 300 \\
\hline 29 & 15000 & 10000 & 8100 & 0 & 400 & 500 & 0 & 70500 & 400 \\
\hline 30 & 12000 & 9000 & 7000 & 0 & 300 & 1000 & 0 & 25000 & 0 \\
\hline 31 & 20000 & 14000 & 12000 & 0 & 1000 & 1000 & 0 & 25700 & 300 \\
\hline 32 & 6000 & 8000 & 7500 & 0 & 200 & 500 & 1 & 21500 & 500 \\
\hline 33 & 15000 & 8500 & 7300 & 0 & 300 & 800 & 0 & 35000 & 0 \\
\hline 34 & 5000 & 12000 & 10200 & 0 & 700 & 1000 & 0 & 50500 & 350 \\
\hline 35 & 15000 & 11000 & 8800 & 0 & 0 & 500 & 0 & 19000 & 400 \\
\hline 36 & 13000 & 12000 & 9600 & 0 & 500 & 1000 & 1 & 98700 & 300 \\
\hline
\end{tabular}


Informal Economy of Dhaka City (South): Situation and Facts

\begin{tabular}{|c|c|c|c|c|c|c|c|c|c|}
\hline $\begin{array}{l}\text { Sl } \\
\text { No }\end{array}$ & $\begin{array}{l}\text { initial } \\
\text { investment }\end{array}$ & Income & Expenditure & $\begin{array}{l}\text { other } \\
\text { occupation }\end{array}$ & $\begin{array}{l}\text { payment } \\
\text { business } \\
\text { purpose }\end{array}$ & savings & borrowings & asset & tobacco \\
\hline 37 & 10000 & 13000 & 11200 & 0 & 900 & 700 & 1 & 79000 & 300 \\
\hline 38 & 8000 & 12000 & 11600 & 0 & 200 & 0 & 0 & 58000 & 400 \\
\hline 39 & 12000 & 14000 & 11600 & 0 & 500 & 1000 & 0 & 63500 & 400 \\
\hline 40 & 13000 & 11000 & 9600 & 0 & 400 & 1000 & 0 & 40000 & 500 \\
\hline 41 & 12000 & 12000 & 10400 & 0 & 1500 & 500 & 1 & 67000 & 400 \\
\hline 42 & 8000 & 8000 & 6000 & 0 & 250 & 1000 & 0 & 30000 & 0 \\
\hline 43 & 5000 & 14000 & 10350 & 0 & 900 & 0 & 1 & 20000 & 300 \\
\hline 44 & 8000 & 17000 & 11800 & 0 & 500 & 3000 & 0 & 76000 & 400 \\
\hline 45 & 10000 & 10000 & 8000 & 0 & 500 & 500 & 0 & 88200 & 200 \\
\hline 46 & 5000 & 12000 & 10100 & 0 & 900 & 500 & 0 & 88200 & 300 \\
\hline 47 & 6000 & 21000 & 15900 & 0 & 900 & 1500 & 0 & 78000 & 350 \\
\hline 48 & 9000 & 10000 & 9500 & 0 & 0 & 0 & 1 & 12400 & 300 \\
\hline 49 & 7000 & 9000 & 7200 & 0 & 300 & 1500 & 0 & 23000 & 0 \\
\hline 50 & 6000 & 8000 & 6800 & 0 & 200 & 500 & 0 & 27000 & 0 \\
\hline
\end{tabular}

Citation: A H M Shahidul Islam. "Informal Economy of Dhaka City (South): Situation and Facts" American Research Journal of Humanities and Social Sciences, vol 4, no. 1, 2018, pp. 1-20.

Copyright (C) 2018 A H M Shahidul Islam, This is an open access article distributed under the Creative Commons Attribution License, which permits unrestricted use, distribution, and reproduction in any medium, provided the original work is properly cited. 